\title{
Continuing professional development of teachers in global learning: What works?
}

Clare Bentall UCL Institute of Education

\section{Introduction}

Since the 1960's, NGOs have been involved in the implementation of development education and global learning within schools: providing resources, delivering lessons and activities for pupils and in providing continuing professional development (CPD) for teachers (Mundy and Manion 2008, Tallon and Milligan 2018, Tarozzi and Inguaggiato 2018). Where there is varying political support for global education, and little coverage in pre-service teaching training, such CPD remains crucial in supporting teachers. However, there have been concerns about the levels of provision and quality of CPD for global learning in formal education (DEF and DEEEEP 2009). There are also concerns about the distinction between advocacy and education with externally provided CPD (Bourn 2016). There is also evidence, however, that it can be effective. Simpson's (2017) and Cusack and Rush's (2010) analyses of certain interventions illustrate that teachers do develop when provided with the opportunity. McCarthy and Gannon's (2016) evaluation of an Irish development education programme also demonstrates that CPD needs to be included in support for schools. There are also articles on pre-service teacher training (e.g. Dariji and Lang-Wojtasik 2014, Kirkwood-Tucker et al 2011, Scoffham 2014), on the competencies teachers and educators need, which have implications for all teacher development (Büker and Schell-Straub 2017, Scheunpflug 2011). This literature all points to the potential for CPD for global learning, though detailed evidence of what makes it effective is limited.

In this chapter, I contribute to addressing this gap this by analysing the experience of teachers and schools engaging with externally provided CPD as part of the Global Learning Programme (20132018) in England (GLP-E). Firstly, I identify key characteristics of effective CPD for global learning. Global learning is the current term used to refer to global education in the UK, and I define it briefly in the literature discussion. Then I outline the approaches to CPD within GLP-E, and to the data collection and analysis. In discussing the findings, I argue that CPD for global learning can inspire teachers to a renewed commitment to teaching through the impact on pupils' learning. With the support of external expertise, it can meet teachers' needs to explore and develop pedagogical approaches, and through collaborative models and suitable follow up, it can support more sustained engagement with global learning. But this is also contingent on support being available for schools and CPD providers to develop relevant courses that respond to teacher and pupil needs.

\section{Effective CPD for global learning}

CPD is linked to improved teaching and student learning (see Timperley et al 2007, Hanushek and Rivkin 2012), therefore it is reasonable to anticipate that CPD for global learning can have similar outcomes. However, this requires understanding what makes such CPD effective. Before examining the evidence in the literature, CPD and global learning need defining.

Day's (1999:4) definition of CPD sets out the full scope and purpose of CPD:

Professional development consists of all natural learning experiences and those conscious and planned activities which are intended to be of direct benefit to the individual, group or school and which contribute, through these, to the quality of education in the classroom. It is the process by which, alone and with others, teachers review, renew and extend their 
commitment as change agents to the moral purposes of teaching; and by which they acquire and develop critically the knowledge, skills and emotional intelligence essential to good professional thinking, planning and practice with children, young people and colleagues through each phase of their teaching lives.

This definition prioritises teachers' and pupils' learning (see Avalos 2011, Beijaard et al 2007, Murphy and de Paor 2017, Postholm 2012, Vescio et al 2008) and rejects teacher-as-technician delivery models (Dadds 2014) and deficit approaches (Hardy and Rönnerman 2011).

Global learning has many definitions (see Bourn 2012). In this chapter I understand it to be learning that prepares people for life in a globalised world, that challenges them engage in and understand their personal responsibility for global social justice (Scheunpflug 2008). Content and approaches vary. However, there is usually a focus on global issues, learners' experiences of these in relation to their local contexts, and critical exploration of development, poverty and power relationships globally (Foghani-Arani and Hartmeyer 2010). This is accompanied by the development of associated skills and attitudes, such as critical thinking, and a pedagogical approach that prioritises multiple perspectives and participatory activities. Global learning demands a move from awareness of issues to action for a better world (Andreotti 2010, Asbrand 2008). The theory underpinning the GLP's approach also emphasised a focus on social justice, reflection and dialogue, understanding power globally, and developing a 'global outlook' (Bourn 2014:5).

Clearly an important starting point for any CPD, but particularly CPD for global learning, an area which cuts across subject disciplines and rarely is the basis for teachers' initial qualifications, is the teachers' subject knowledge (see Cordingley et al 2015). If teachers are to support pupils' learning about global issues, they need to enhance their own knowledge, and explore their values and attitudes towards those global issues (Scheunpflug 2011). This knowledge can come from external sources, such as CPD providers, research evidence, or teachers' reflection on practice and collaboration with peers (Cochran-Smith and Lytle 1999).

Global learning has a strong values base, a focus on social justice, and requires critical selfexamination on attitudes, values and beliefs. For teachers to help pupils develop a global mindset and characteristics of citizens willing to act for social justice, they need to experience a similar transformation (Andreotti in Bourn 2015, Dariji and Lang-Wojtasik 2014, Scheunpflug 2011). Creating a sense of disjuncture between existing and new understandings is important (Mezirow 2000), so that teachers learn new things that are not congruent with existing understandings, as well as ones that are (Timperley et al 2007). This requires an attitude of inquiry and reflection (Capps et al 2012, McArdle and Coutts 2010).

CPD should challenge teachers' beliefs (Cordingley et al 2015). These beliefs are informed by practice, particularly by teachers' experience of changes in their pupils' learning (Guskey 2002), which presents a challenge if teachers have limited experience of global learning. Their beliefs are therefore more amenable to change in-service, for example through CPD (Ofper et al 2011), but they need some experience to reflect on. Time and on-going support are therefore important. Teachers need to be able to learn new approaches, implement, reflect and refine them (Capps et al 2012), meaning one-off CPD events are likely to be less effective (El-Deghaidy et al 2013, Opfer and Pedder 2011b).

Teachers also need to develop subject-specific pedagogical knowledge (Cordingley et al 2015, Shulman 1986). Global learning has a 'commitment to interactive and participatory pedagogies' (Scoffham 2014: 29) with multiple perspectives offered and all voices heard (Bennell 2015). If CPD is most effective when it 'requires teachers to learn in ways that reflect how they should teach pupils' (Opfer and Pedder 2011a: 385), CPD for global learning needs to prioritise the same interaction and participatory approaches with teachers. 
An extension of this interaction and participation is the creation of opportunities for genuine collaboration, within or between schools. With collaboration, 'a learning community emerges, the participating teachers are more likely to discuss problems, strategies, and solutions. Change in teaching behaviour then becomes an ongoing, collective responsibility rather than an individual one' (Opfer and Pedder 2011a: 385). Ultimately, CPD for global learning asks teachers to consider what type of world they want for their pupils, and how to help them prepare for it. Collective opportunities to discuss their 'aspirations for their pupils' and develop a shared sense of purpose are therefore crucial (Cordingley et al 2015:5).

CPD for global learning, with its focus on real-world issues that concern pupils, has the potential to tap into teachers' motivations, in ways other mandated CPD may not. Motivation for CPD is affected by teachers' personal desire to grow, school policy, whether CPD is part of school culture (McMillan et al 2016) and teachers' orientation towards subject or learner (see de Vries et al 2013). It is also influenced by teachers' agency in the design and implementation of CPD (Mansour et al 2014). Effective CPD for global learning therefore requires collaboration between teachers, schools and external providers as to its form and approach.

To deliver CPD as described above, external providers need a commitment to the principles and approaches to global learning. They need to help teachers make sense of difficult and often controversial topics, present and model appropriate pedagogy. They need to understand teachers' starting points, build relationships with them, understand their school contexts, yet also challenge their existing understandings and beliefs (see Cordingley et al 2015: 6-7). The use of external expertise is, however, no guarantee of teachers' learning. Facilitators of CPD for global learning need suitable training and the development of relevant competencies (Büker, and Schell-Straub 2017). As Timperley et al (2007: xxix) conclude, 'experts need more than knowledge of the content of changes in teaching practice that might make a difference to students; they also need to know how to make the content meaningful to teachers and manageable within the context of teaching practice' and such 'provider pedagogical content knowledge' comes through training and experience.

\section{GLP-E and the UK global learning context}

CPD for global learning In the UK started in the 1960s, when international NGOs, such as Oxfam, were working to educate the public on aid and development issues (Harrison 2008). In 1975, the first Development Education Centre (DEC) was set up at Selly Oak college, with the support of the City council and Oxfam. A network of DECs then grewi By 1993, when the Development Education Association (DEA) was established, there were 230 organisations, campaigning and working in

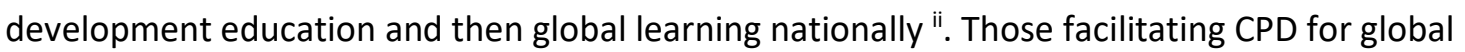
learning come from a variety of backgrounds, with different levels of training (Büker and SchellStraub 2017). As in other contexts, UK government funding for global learning in schools comes from the ministry for overseas development (Surian 2001, Tarozzi and Inguaggiato 2018). In 2012, the ministry decided to fund a national Global Learning Programme.

The GLP-E (2013-2018) had a focus on pupils ages 7-11 and ages 11-14 (end of primary and beginning of secondary). Its aims were to:

- Help teachers to encourage children and young people to understand their role in a globallyinterdependent world and to explore strategies by which they can make it more just and sustainable 
- Provide strategies to familiarise pupils with the concepts of interdependence, development, globalisation and sustainability

- Enable teachers to move pupils from a charity mentality to a social justice mentality

- Provide strategies for teachers to stimulate critical thinking about global issues both at whole school and at pupil level

- Help schools to promote greater awareness of poverty and sustainability

- Enable schools to explore alternative models of development and sustainability in the classroom

Schools joined in different cohorts (Waves) for 5 terms. For each Wave, Expert Centre (ECs) schools (those with more experience of global learning) recruited Partner Schools (PSs), forming local networks. The ECs, supported by 16 local and 4 national advisors, ran CPD sessions for their networks, covering some compulsory and optional topics. In addition, GLP-E offered each school $£ 500$ to spend on externally provided CPD, on condition of completing an initial audit of their school's work in global learning (Whole-school audit WSA1). This involved a self-assessment of their work on global learning using an online tool. This externally provided CPD is the focus of this chapter.

\section{Externally provided CPD}

109 organisations registered as CPD providers and had courses approved, of which 71 had courses booked. The organisations included the network of Development Education Centres (CODEC), international NGOs, smaller organisations and individual consultants. The approval process involved checking whether courses met GLP-E aims, used appropriate training methods, and were run by experienced trainers. Courses, on a wide range of topics, included whole-school courses; courses related to awards; full-day, half-day, after school (twilight) courses; and conference packages. The cost, set by the providers, ranged from $£ 45$ to $£ 500$, meaning schools could book more than one course.

Overall, 2552 out of 7843 schools (32.5\%) registered on GLP-E booked externally provided CPD, with 11977 teacher attendances. This was $61.8 \%$ of the sub-total of 4125 schools eligible to receive the f500 funding for CPD, having completed WSA1. The biggest challenge to schools was finding time to decide what CPD would best suit their schools' priorities and then scheduling it. The data discussed below is from those schools that were able to attend CPD.

\section{Methods}

GLP-E recruited a record number of schools to date on a single government funded global learning programme in England, so there is a wealth of data generated. My role in overseeing the externally provided CPD, including assuring the quality of provision, gave me access to this data. I draw on a selection in this chapter:

- Booking and attendance statistics

- Observations of 23 courses

- Teacher course evaluations

- Provider feedback

- 8 interviews with lead teachers

In the discussion below, I quote from statistics, observations and interviews, and use the provider and evaluation data as context. The interviews were undertaken with 8 (from 48) schools that booked additional CPD. (68\% of eligible schools only booked one course.) The interviews provided interesting perspectives on the impact of longer-term engagement with CPD. I chose semi- 
structured phone interviews to provide answers to specific questions and to allow teachers to describe their experience in depth (Lechuga, 2012). These were recorded with the teachers' permission. They were sent a transcript and a draft of the final programme report to check. Ethics approval was granted by UCL IOE ethics review committee. The data was analysed using a standard content analysis with coding and a search for themes (Cohen et al., 2011). The quotations from teachers are pseudonymised $(A-H)$.

\section{Effective externally provided CPD for global learning}

The most interesting findings to emerge in relation to how teachers responded to CPD, what they found most helpful and effective, are about teachers regaining a sense of purpose, the importance of pedagogy, the value of collaboration and longer-term engagement with CPD.

Regaining a sense of purpose

I start with the effect of CPD for global learning on teachers and pupils as it needs to motivate teachers to further engage with global learning, if it is to have lasting impact.

Much has been written on problems with different forms of CPD (Done et al 2011), so it was particularly heartening that teachers found the CPD for global learning 'professionally leavening' (Sugrue and Mertkan 2017: 172). It increased their confidence and enthusiasm for teaching, a finding supported by other GLP-E evaluation dataiii. For example, Teacher G, said, 'that last year was probably the best year of my entire teaching career and a big part of it was because I was involved in a lot of CPD. And I just felt that I had really developed as a teacher and...I have learnt a lot of new things'. CPD for global learning is particularly inspiring when linked to individuals' motivations and sense of their identity as teachers, in contexts where this can easily get lost. As one group I observed commented, it 'reminds you what teaching is about'.

Teachers identified that global learning CPD offered them a new direction. For example, Teacher B said it 'ignites something in terms of a passion for teaching and a desire to do things a bit differently'. The response from pupils was key. As Vescio et al (2008) point out, CPD must link to pupils' learning. Teacher $Y$ explained, 'It has been the children who have responded positively. They've learnt things from it, they've started questioning things more. And I just thought, this is fantastic - and it's just sort of grown. Had the children not responded so, then I wouldn't have pursued it'.

Clearly, it is not possible to claim a universal effect from a small interview sample. But the overwhelmingly positive evidence from course evaluations confirms that the focus on teaching pupils to engage with global issues and consider their place in a globalised world, relates directly to teachers' intrinsic motivation for teaching, their 'moral purpose' (Day 1999).

\section{Knowledge and pedagogy}

Having established that CPD for global learning can motivate teachers to re-engage with their professional practice, it is important to understand how it achieves that. The literature clearly lists many characteristics of effective CPD which are potentially important features of CPD for global learning (see Cordingley et al 2015, DFES 2016). This includes focus on subject knowledge and subject-specific pedagogy. The responses of teachers to these aspects of CPD were particularly interesting.

Given that GLP-E had a clear emphasis on developing pupils' knowledge, particularly of development and poverty, and that many teachers would not have covered knowledge of global issues in preservice training, one might expect they would choose opportunities to improve their own knowledge. However, the CPD courses on specific global issues were less popular than generic global learning courses, or bespoke courses designed in consultation with schools. For example, courses 
with development and poverty as the main theme accounted for only 49 out of 11977 teacher attendances $(0.4 \%)$ and only 742 attended courses on sustainability and environmental courses.

There are various possible explanations, including potentially some mismatch between programme and school priorities; the challenge for teachers of subjects other than geography, history or economics to see the relevance for their learners; or a need for more introductory courses. $58 \%$ of schools starting on GLP-E self-assessed as having no experience of global learning, so this choice is logical. However, the data suggests that an additional key explanation is a preference for learning content through pedagogy (Timperley et al 2007).

This can be illustrated with the example of Philosophy for Children (P4C) courses, which had 2574 (21\%) teacher attendances, and the popularity of courses focusing on linking global learning to the curriculum. P4C is an approach that helps children learn to communicate more effectively and think critically iv and can be used with all ages. It teaches pupils to listen to alternative viewpoints, make their case, come to their own conclusions, in a 'community of enquiry'. The teacher, using stimuli such as stories or pictures, facilitates a process where children generate philosophical questions to discuss. The children chose a question and the teacher facilitates a group discussion, in which there are clear rules on turn-taking, listening, presenting views etc. It is particularly well-suited to global learning, as the stimuli can be about global issues, the method is participatory and it emphasises using critical thinking (Bourn et al 2016).

What the P4C and other courses on the programme had in common was an experiential, inquirybased, participatory approach, which modelled teaching, used activities relevant for the content and thereby connected to classroom experience (Capps et al 2012). Teachers experienced activities that served multiple purposes simultaneously, and that reflected approaches to pupils' learning (Cordingley et al 2015). Teachers therefore gained an understanding of a pedagogical approach that they could apply across subjects and topics. Teacher E's response was illustrative: 'actually, it's the methodology that I realised is part of the key of it: not just the content, but ways to engage children and make them better learners.' This was also illustrated in the action points set by one group I observed: 'teach how we can impact the future, joined up view of the world, encourage children to look further than the local environment, talk more about the world, use critical thinking'. Teachers also need concrete ideas of how to implement a new approach, and practical suggestions on incorporating global learning and guidance on using resources were the two most cited benefits in the interviews and were frequently mentioned in course evaluations. But it seemed that it was the combination of theory and practice that matters (Timperley et al 2007). The contextualising of pupil activities and interesting resources within an overall approach helped teachers see how to improve their pupils' learning.

\section{Collaboration}

Another key feature that teachers valued was the opportunity to collaborate, share and discuss approaches with peers, within and between schools. Collaboration is recommended in the literature, generally (see Kennedy 2011), but it is particularly relevant for global learning. It reflects global learning principles and gives less experienced teachers opportunities to learn from others. In contexts with no or limited curriculum guidance, embedding global learning within a school is also only possible if teachers share their understandings.

Whole-school and 'cluster' CPD were the two main collaborative models on GLP-E. Whole-school CPD was popular with schools that had timetable space and with small schools, where all staff could participate. This reflects a common teacher preference for in-house CPD, where collaboration is in 'an authentic context' (Mansour et al 2014: 968). There are many benefits of whole-school CPD. It can link to school development plans. For example, I observed a whole-school CPD in a primary school in the North West, where the headteacher had prioritised implementing P4C for the coming 
school year. Whole-school CPD ensured all staff developed shared understandings of P4C and agreed implementation strategies. In another example, Teacher C found whole-school CPD 'was an opportunity of looking at our curriculum and seeing where we could really embed it'.

Cluster CPD was CPD for a group of schools. Where existing EC networks chose this approach, they could continue to work with each other as an extension to the network CPD, with more opportunities to reflect on implementation (McArdle and Coutts 2010). Some were able to plan their external CPD to fit the timetable of the EC twilight sessions so developing a logical, coherent thread of learning (Cordingley et al 2015). These networks developed into informal communities of practice, providing opportunities for exploring new understandings and applications to teaching, and reflecting on the impact on pupils' learning (Timperley et al 2007).

One of the main benefits of collaborative approaches is in ensuring sustainability of global learning, by developing a sense of collective responsibility (Ofper and Pedder 2011a). Teacher D said, 'everybody is doing the same thing at the same time. And the conversations that come out of that as well, out of those sessions, can be quite good. Learn and take the subject...take you further'. Teacher $B$ found sharing 'a very motivating thing and, as I say, there aren't loads of opportunities for that anymore'. As some of the providers pointed out, the challenge is in creating the thinking space for teachers and school to engage with global learning.

The social aspect of the learning also matters, as teachers prefer to develop professional knowledge with others (Mansour et al 2014). 'It is through addressing the challenge of this creative tension between the individual and the social that professionals, through negotiation of ideas and actions for change with others, can be assisted to make sense of their own practice and attempts at professional renewal' (McArdle and Coutts 2010: 213).

\section{Follow up and consolidation}

Judging the effectiveness of CPD requires considering its longer-term impact. Guskey (2002) argues that teachers' beliefs about their practice change after implementation and seeing the improvement in pupils' learning. One-off CPD events, though useful and inspiring, are unlikely to be best for sustained change. Ongoing support is important (De Paor 2016). One of the less successful aspects of the GLP-E CPD was that most schools booked relatively late (in term 4 or 5), for very understandable practical reasons. But this meant only 48 schools booked more than one course, despite many schools not having spent their full $£ 500$. The experience of teachers from schools that were able to consolidate their learning in various ways is therefore particularly valuable.

Some providers offered bespoke courses which were designed in two parts to maximise opportunities for teachers to learn together and implement in their own classrooms and schools, with follow up to reflect and share. Teacher A liked this format: 'that was the idea, that you went away and tried things and came back and discussed and reflected on what you'd done'. In other examples, schools chose different types of CPD to build their learning. Teacher F was inspired by one course, which opened her eyes to the lack of experience of diversity in her rural school. So, she then chose a course linking to a school in London, enabling her 'to access something that I don't think we would have done otherwise'. Others consolidated by re-running the CPD for different parts of the school community. Teacher $G$ took a course, then booked a whole-school version. Attending as an individual increased her confidence to advise colleagues, and helped her assess what they would find useful, whilst booking a provider for the follow-up gave others the opportunity to benefit from external expertise. Teacher D booked a course on values for parents, pupils and the wider school, having initially booked one for teaching staff. She saw this as part of a 2 to 3-year process to embed the learning in the school, as she said effort was needed not to 'revert to what you know and are comfortable with'. Finding ways to deliver CPD and support teachers over the longer term is 
important for sustainability. Otherwise global learning becomes something interesting that maybe a small number of teachers, or just an individual, experiences and then the realities of school life erode their commitment and possibilities to influence practice more widely.

\section{Discussion and implications}

This chapter has focused on how teachers on one programme responded to CPD for global learning, what they found most effective, what they prioritised in terms of the focus of that CPD. Clearly this was a specific context, one of the first national programmes for schools in this area, and a new initiative within the UK. However, the findings are more widely relevant and have implications for sustainability of global learning within schools.

As stated at the outset, there are few places globally that have a coordinated national strategy for global learning that involves government, schools, teacher training institutions and NGOs (Tarozzi and Inguaggiato 2017). Global learning is not routinely included in pre-service teacher education, and therefore CPD, delivered mainly by external organisations, remains the core of teacher support. There are few signs, in the UK at least, that this is likely to change, though there is continued focus on school to school support through networks. With increasing pressures on schools and teachers, with greater focus on managerial approaches and accountability for school performance, and issues with funding, global learning is not an education priority. However, the global context sees increased focus on the SDGs, including education for global citizenship, and young people becoming increasingly vocal about their concerns for the future. As I write, pupils globally are engaged in a series of strikes to protest at adults' inadequate responses to climate change. In a sense, there has not been a greater need for quality education that prepares young people for a more uncertain, globalised world. This in turn requires motivated, committed and appropriately trained teachers. In this context, CPD for global learning, provided by external organisations remains a key mechanism for achieving this.

However, that CPD also needs to be effective. Again, it is worth stressing that unlike some other CPD provision which essentially updates already well qualified teachers, CPD for global learning can be teachers' first exposure. Any programme of support needs to factor in the time for schools to decide their priorities, choose relevant CPD, fit it in the timetable, implement the learning, assess the impact and response from pupils, reflect and identify further needs. This requires more than one-off CPD events, however inspiring. External providers and schools need to be supported to provide opportunities to challenge teachers' beliefs, encourage and support them in trying out different pedagogical approaches, give them confidence to tackle difficult issues in the classroom and undergo a process of change in relation to their practice, and possibly their identity as teachers. As it takes courage to undertake such a process of transformation (Kennedy 2005), this is unlikely to be achievable without ongoing support.

This is also best achieved collaboratively, within or between schools and schools need to retain their agency in deciding what CPD is relevant. Although CPD for individual teachers' development is important (Postholm 2012) and individual champions within schools can do amazing work in inspiring and training colleagues, relying on their motivation, energy and enthusiasm is not sustainable. Unless global learning becomes a mandated part of national curricula, prioritising it will remain at the discretion of schools' senior management. External experts can take pressure of expertise away from senior staff, allowing those staff to participate more fully in the CPD, thereby fostering sense of collective responsibility (Opfer and Pedder 2011a).

Finally, it is worth considering the wider benefits of CPD for global learning for the education profession. Where education systems like the English system face increasing levels of teacher turnover and burnout (Worth et al 2017), CPD for global learning could be part of the solution. CPD 
which has the potential to re-ignite teachers' passion for teaching, reinforces their intrinsic motivation, and which reflects 'their aspirations for their pupils' (Cordingley et al 2015), offers a way of supporting teachers to do more than survive. But this will only work with a flourishing third party sector, appropriately equipped and funded to support schools. This includes opportunities for newer providers to develop their 'pedagogical content knowledge' (Timperley et al 2007: xxix), if the quality of that CPD is to be maintained.

\section{Bibliography}

Andreotti, V. (2010), 'Global education in the ' $21^{\text {st }}$ Century': two different perspectives on the 'post-' of postmodernism', International Journal of Development Education and Global Learning, 2 (2): 5-22.

Asbrand, B. (2008), 'How adolescents learn about globalisation and development'. In D. Bourn (ed), Development education debates and dialogues, (28-44), London: Institute of Education, University of London.

Avalos, B. (2011), 'Review: Teacher professional development in Teaching and Teacher Education over ten years', Teaching and Teacher Education, 27: 10-20.

Beijaard, D., F. Korthagen and N. Verloop (2007), 'Understanding how teachers learn as a prerequisite for promoting teacher learning', Teachers and Teaching, 13(2): 105-108.

Bennell, S. J. (2015), 'Education for sustainable development and global citizenship; leadership, collaboration and networking in primary schools', International Journal of Development Education and Global Learning, 7(1): 5-32.

Bourn, D. (2012), 'Development education', in J. Arthur and A. Peterson (eds), The Routledge Companion to Education, London: Routledge.

Bourn, D. (2014), The theory and practice of global learning, Research paper 11 for the Global Learning Programme, London: Development Education Research Centre, Institute of Education

Bourn, D. (2015), 'Teachers as agents of social change', International Journal of Development Education and Global Learning, 7(3): 63-77.

Bourn, D., F. Hunt, N. Blum and H. Lawson (2016), Primary Education for Global Learning and Sustainablity, York: Cambridge Primary Review Trust.

Büker, G. and S. Schell-Straub (2017), 'Global how? - Linking practice to theory: A competency model for training global learning facilitators', International Journal of Development Education and Global Learning, 9 (2): 71-83.

Capps, D.K., B.A. Crawford and M.A. Constas (2012), 'A Review of Empirical Literature on Inquiry Professional Development: Alignment with Best Practices and a Critique of the Findings', Journal of Science Teacher Education, 23: 291-318.

Cochran-Smith, M. and S.L. Lytle. (1999), 'Relationships of knowledge and practice: Teacher learning in communities', in A. Iran-Nejar, and P. D. Pearson (eds.), Review of research in Education, 249-305, Washington, DC: AERA. 
Cohen L., L. Manion and K. Morrison (2011), Research methods in education, $7^{\text {th }}$ edn, London and New York: Routledge.

Cordingley, P., S. Higgins, T. Greany, N., Buckler, D. Coles-Jordan, B. Crisp, L. Saunders and R. Coe (2015), Developing Great Teaching: Lessons from the international reviews into effective professional development, Teacher Development Trust.

Cusack, M. and A. Rush (2010), The authority of a lived experience': An investigation of study visits as a professional development opportunity for post-primary development educators, Policy and Practice: A Development Education Review, 10: 9-24.

Dadds, M. (2014), 'Continuing Professional Development: nurturing the expert within', Professional Development in Education, 40(1): 9-16.

Dariji, B.B. and G. Lang-Wojtasik (2014), 'Preparing globally competent teachers: Indo-German perspectives on teacher training', International Journal of Development Education and Global Learning, 6(3), 49-62.

Day, C. (1999), Developing teachers: the challenges of lifelong learning, London: Falmer.

Development Education Forum (DEF) and Development Education Exchange in Europe Project (DEEEP) (2009), Development Education and the School Curriculum in the European Union: A report on the status and impact of development education in the formal education sector and school curriculum in member states of the European Union, Brussels: DEEEP.

DFES (2016), Standard for teachers' professional development Implementation guidance for school leaders, teachers, and organisations that offer professional development for teachers, London: Department for Education.

De Paor, C. (2016), 'The impact of school-based continuing professional development: views of teachers and support professionals', Irish Educational Studies, 35(3): 289-306.

De Vries, S., W. J.C.M. van de Grift and E. P.W.A. Jansen (2013), 'Teachers' beliefs and continuing professional development', Journal of Educational Administration, 51(2): 213-231.

Done, E., H. Knowler, T. Rea and K. Gale (2011), '(Re)writing CPD: creative analytical practices and the 'continuing professional development of teachers", Reflective Practice, 12(3): 389-399.

El-Deghaidy, H., M. Mansour and S. Alshamrani (2015), 'Science teachers' typology of CPD activities: a socio-constructivist perspective', International Journal of Science and Mathematics Education, 13(6): 1539-1566.

Foghani-Arani, N. and H. Hartmeyer (2010), 'Global learning in Austria: Towards a national strategy and beyond', International Journal of Development Education and Global Learning, 2(3): 45-58.

Guskey, T. (2002), 'Professional Development and Teacher Change', Teachers and Teaching: theory and practice, 8 (3/4): 381-391.

Guskey, T. R. (2003) 'What makes professional development effective?' Phi Delta Kappan, 84 (10): 748-750. 
Hanushek, E. and S. Rivkin (2012), 'The distribution of teacher quality and implications for policy', Annual Review of Economics, 4:131-57.

Hardy, I. and K. Rönnerman (2011), 'The value and valuing of continuing professional development: current dilemmas, future directions and the case for action research', Cambridge Journal of Education, 41(4): 461-472.

Harrison, D.G. (2008), 'Oxfam and the rise of development education in England from 1959 to 1979', Unpublished PhD thesis, Institute of Education, London.

Hunt, F. (2012), Global learning in Primary schools in England: Practices and impacts, DERC Research Paper no.9, London: Institute of Education.

Kennedy, A. (2005), 'Models of continuing professional development: a framework for analysis', Journal of In- service Education, 31(2): 235-250.

Kennedy, A. (2011), 'Collaborative continuing professional development (CPD) for teachers in Scotland: aspirations, opportunities and barriers', European Journal of Teacher Education, 34(1):2541.

Kirkwood-Tucker, T.F., J. D. Morris and M.G. Lieberman (2011), 'What kind of teachers will teach our children? The worldmindedness of undergraduate elementary and secondary Social Studies teacher candidates at five Florida public universities', International Journal of Development Education and Global Learning, 3(3): 5-28.

Lechuga, V.M. (2012), 'Exploring culture from a distance: the utility of telephone interviews in qualitative research', International Journal of Qualitative Studies in Education, 25(3): 251-268.

Mansour, N., H. EL-Deghaidy, S. Alshamrani and A. Aldahmash (2014), 'Rethinking the Theory and Practice of Continuing Professional Development: Science Teachers' Perspectives', Res Sci Educ 44: 949-973.

McArdle, K. and N. Coutts (2010), 'Taking teachers' continuous professional development (CPD) beyond reflection: adding shared sense-making and collaborative engagement for professional renewal', Studies in Continuing Education, 32(3): 201-215.

McCarthy, M. and M. Gannon (2016), 'Embedding development education in post-primary teaching and learning: lessons from Worldwise Global Schools', Policy and Practice: A Development Education Review, 23, 102-123.

McMillan, D.J., B. McConnell and H. O'Sullivan (2016), 'Continuing professional development - why bother? Perceptions and motivations of teachers in Ireland', Professional Development in Education, 42(1): 150-167.

Mezirow, J. (2000), 'Learning to think like an adult: core concepts of transformation theory. In J. Mezirow and associates', Learning as Transformation: Critical perspectives on a theory in progress. San Francisco: Jossey-Bass.

Mundy, K. and C. Manion (2008), 'Global Education in Canadian Elementary Schools: An Exploratory Study', Canadian Journal of Education, 31(4): 941-974. 
Murphy, T. R. N. and C. de Paor (2017), 'Teachers' CPD and sectoral interests: Opportunities for convergence and divergence', Teaching and Teacher Education, 66: 242-249.

Opfer, V.D. and D. Pedder (2011a), 'Conceptualising professional learning', Review of Educational Research, 81(3): 376-407.

Opfer, V.D. and D. Pedder (2011b), 'The lost promise of teacher professional development in England', European Journal of Teacher Education, 34(1): 3-24.

Opfer, V.D., D. Pedder and Z. Lavicza (2011), 'The role of teachers' orientation to learning in professional development and change: A national study of teachers in England', Teaching and Teacher Education, 27: 443-453.

Postholm, M. B. (2012) 'Teachers' professional development: a theoretical review', Educational Research, 54(4): 405-429.

Sachs, J. (2007), Learning to improve or improving learning: the dilemma of teacher continuing professional development, Proceedings of the 20st Annual World ICSEI Congress 3-6 January 2007, Convention Center Bernardin Portorož, Slovenia.

Scheunfplug, A. (2008), 'Why global learning and global education? An educational approach influenced by the perspectives of Immanuel Kant', in D. Bourn (ed) Development Education Debates and Dialogues, 18-27, London: Institute of Education, University of London.

Scheunpflug, A. (2011), 'Global education and cross-cultural learning: A challenge for a researchbased approach to international teacher education', International Journal of Development Education and Global Learning, 3(3): 2-44.

Scoffham, S. (2014), "Do we really need to know this?' The challenge of developing a global learning module for trainee teachers', International Journal of Development Education and Global Learning, 5(3): 28-45.

Shulman, L. S. (1986), 'Those Who Understand: Knowledge Growth in Teaching', Educational Researcher, 15(2): 4-14.

Simpson, J. (2017), "Learning to unlearn the charity mentality within schools', Policy and Practice: A Development Education Review, 25, 88-108.

Sugrue, C. and S. Mertkan (2017), 'Professional responsibility, accountability and performativity among teachers: the leavening influence of CPD?' Teachers and Teaching, 23(2); 171-190.

Surian, A. (2001), 'A comparative look at European policies on development education', The Development Education Journal, 7(2): 4-7.

Tallon, R. and A. Milligan (2018), 'The changing field of development and global education resource provision in New Zealand', International Journal of Development Education and Global Learning, 10 (1): 59-71.

Tarozzi, M. and C. Inguaggiato (2018), 'Implementing global citizenship education in EU primary schools: The role of government ministries', International Journal for development education and global learning, 10(1): 21-38. 
Timperley, H., A. Wilson, H. Barrar and I. Fung (2007), Teacher Professional Learning and Development Best Evidence Synthesis Iteration [BES], Ministry of Education, Box 1666, Wellington, New Zealand.

Vescio, V, D. Ross and Adams, A. (2008), 'A review of research on the impact of professional learning communities on teaching practice and student learning', Teaching and Teacher Education, 24: 8091.

Worth, J., G. De Lazzari and J. Hillary (2017), Teacher Retention and Turnover Research: Interim Report, Slough: NFER.

\footnotetext{
i see CODEC: http://www.codec.org.uk/.

ii https://www.eldis.org/organisation/A1564

iii See chapter in this volume by Hunt

iv https://www.sapere.org.uk/about-us.aspx
} 